\title{
Willingness to Pay for Green Building Features in the Medium-Income Residential Market of Makurdi, Nigeria
}

\author{
Vincent Kpamsar Takuh ${ }^{1}$, Adegbenga Adeyemi ${ }^{1}$, Muhammad Umar Bello ${ }^{1}$
}

\author{
${ }^{1}$ Abubakar Tafawa Balewa University \\ Tafawa Balewa Way, P. M. B. 0248, Bauchi, 740272, Nigeria
}

\section{DOI: $10.22178 /$ pos.76-11}

JEL Classification: E31

Received 27.10.2021

Accepted 25.11.2021

Published online 30.11.2021

Corresponding Author:

Vincent Kpamsar Takuh

kpamvincent@gmail.com

(c) 2021 The Authors. This article is licensed under a Creative Commons Attribution 4.0 License @ (1)
Abstract. Investigating willingness to pay for green buildings in Nigeria and other developing nations is an urgent need since the world is advocating sustainable development, which the building industry must adopt while attempting to satisfy housing needs that are yet to be met in most developing countries. Recognizing that medium-income earners are victims of housing deficit who can afford housing to a reasonable extent in Nigeria, this paper aimed to investigate medium-income householders' willingness to pay for a green residential building to aid green building investment decisions in Makurdi. Three objectives were put in place to pursue the aim in which the study was approached quantitatively and adopted survey strategy using 300 questionnaires as the instruments for data collection as suitable for contingent valuation technique. Data collected were analyzed using the weighted mean, logistic model and multiple regression. The findings were that Makurdi medium-income earners find green features essential and are willing to pay a $3.3 \%$ premium price to purchase residential buildings with green features. Therefore, the paper recommends that the government and private investors strategically consider green residential buildings while creating more awareness of the importance of building green.

Keywords: green building; willingness to pay; contingent valuation; medium-income householders; residential market.

\section{INTRODUCTION}

Man's numerous needs that have called for the continuous exploitation of the Earth's natural resource for development over the last decades have negatively impacted the environment, endangering the survival of the Earth and future generations. The visible evidence is the increasingly unfavourable climate changes and natural disasters seen globally [14]. The construction industry has significantly destroyed the natural environment. It has been a significant consumer of non-renewable natural resources; the industry produces substantial waste, pollutes air and water, and accounts significantly for the greenhouse gas emissions affecting climate change [18]. For instance, [10] reported that buildings represent $38.9 \%$ of primary energy use, $38 \%$ of all carbon dioxide $\left(\mathrm{CO}_{2}\right)$ emissions, and $72 \%$ of electricity consumption in developed nations such as the United States. Buildings also use $13.6 \%$ of all potable water or 15 trillion gallons per year; additionally, $40 \%$ of raw materials used globally are consumed by the building industry ( 3 billion tons annually) [10]. This report is not far from the re- ality in Nigeria's context, if not worse, since Nigeria is still a developing country trying to emulate modernization.

Moderate scenarios developed by the United Nations suggested that, if the current population and natural resource consumption trends continue, humanity will, by the year 2030, require the equivalent of two piles of Earth to support it [8]. Recognizing that the planet's resources are not inexhaustible and that there is a need to conserve the Earth's natural resources, the concept of sustainable development became necessary, which gave rise to the idea of green building to guide the building industry. As against conventional buildings, green buildings seek to use land and energy efficiently, conserve water, improve indoor environmental quality and increase the use of recycled and renewable materials and at the same time improve the well-being of the occupants [4].

The building sector in developed countries has embraced building green and has developed and embraced some green building certification schemes. As a result, these countries have wit- 
nessed a green building revolution, driving design and construction toward sustainability. However, the concept of building green has not been embraced in most developing nations, such as Nigeria, which has yet to develop or adopt a green building certification scheme [22]. In addition, the upfront cost issue in building green is frequently cited as an obstacle to adopting the concept of building green $[23,26]$. However, [11] argued that an ideal green building should not be expensive, should last long with modest maintenance, and return ultimately to the Earth when abandoned. These arguments and the intent to go the noble way of building green while meeting housing demand have motivated the need for this study.

Thus, recognising that over the years housing deficit in Nigeria affects medium and low-income earners, and the debt currently stands at 22 million units, coupled with the increasing need for housing by the aforementioned income groups [1], it is of utmost importance that the government and private developers find an urgent solution to this problem as the importance of housing cannot be overemphasized. With the desire to meet housing needs, coupled with the desire to build green, this paper investigated how willing will medium-income earners be to pay for green building features if provided using the contingent valuation method as also adopted by [22, 27] by creating a hypothetical market and soliciting medium-income householders' opinion on their willingness to pay since there is no evidence of green building in the study area.

The choice of medium-income earners arises as a result of the fact that the national minimum annual income in Nigeria $(\$ 360,000)$ is far below the yearly household income needed to purchase the cheapest newly built house by a formal developer, which in 2018 stood at $\$ 3.09 \mathrm{M}$ [7] hence, justifying the target market as medium income earners who are likely to make effective demand, rather than low-income earners whose demand may not be effective. This has further shed light on the choice of the study area - Makurdi, as medium-income earners predominantly occupy it, basically civil servants and commercial businessmen [16, 19].

This paper aimed to investigate medium-income earners' willingness to pay for green residential building features to aid green building investment decisions in Makurdi.
The following objectives were pursued:

1. To assess medium-income householders' preference of green residential building features in Makurdi.

2. To estimate the amount medium-income householders will pay for a green residential building in Makurdi.

3. To assess the effect of preference for green building features on the amount householders will pay for a green residential building in Makurdi.

\section{LITERATURE REVIEW}

\section{Concept of Green Building}

The idea of green building is considered a way for the building industry to achieve sustainable development goals taking into account environmental, socio and economic issues to protect the environment [30]. Green building is a subset of sustainable building concepts used to describe structures built in an environmentally friendly manner by minimizing resources and ensuring the health and well-being of occupants and the environment both today and for future generations [17]. Authors [21] referred to "Green buildings" as structures with a minimum environmental footprint that optimize the utilization of materials, water, energy and other resources and that mitigate the negative impacts of the building on the health and well-being of occupants. These buildings are usually designed to minimize their environmental footprint and, at the same time, improve the well-being of the persons who occupy the buildings. An ideal green building should not be expensive to build, should last long with modest maintenance, but return entirely to the Earth when abandoned [3].

The concept of green building is based on a life cycle perspective during a building's site selection, design, construction and operation, renovation and demolition. The buildings' adverse effect on the natural environment and human health is minimized [32]. The authors [3] outlined four principles of green building: social, economic, biophysical, and technical. The extent of the principles of the green building mirrors those of sustainable development, which is about synergistic relationships between economic, social and environmental aspects of sustainability. Three general objectives that should shape the framework for implementing green building design and con- 
struction while keeping in mind the sustainability principles have been identified. These objectives are resource conservation, cost efficiency and innovation for human adaptation [3]. As against conventional buildings, green buildings seek to use land and energy efficiently, conserve water, improve indoor environmental quality, and increase recycled and renewable materials [34].

The building industry accounts for a large percentage of greenhouse gas emissions. Therefore, the sector presents opportunities to reduce emissions [34]. A few decades ago, the building sector in developed countries witnessed a green building revolution, driving design and construction toward sustainability. However, green buildings constitute a small subset of existing buildings, increasing gradually [12]. One of the most significant parts of the green building movement was the launch of a series of green building rating systems, guidelines, standards and certifications, such as Leadership in Energy and Environmental Design (LEED) in the United States, Building Research Establishment Environmental Assessment Method (BREEAM) in the United Kingdom, Green Building Label (GBL) of China and Green Star in South Africa [34, 23]. These certification bodies define the extent (features) of what can be called a green building which will be reviewed critically in the next session.

Despite the impetus of environmental movement, the green building faces significant challenges that are traced to non-environmentally friendly habits and require a behaviour change [34]. There have been increasing concerns and controversies surrounding the performance of green buildings. Scholars argue this not as a result of the wrong design of the green building, nor tools, nor techniques nor the technology adopted, but due to the reality that facilities do not use materials such as energy and water, but the occupants do [34]. A green building becomes a greenwash if it relies on technological solutions, such as solar panels and thermal insulation, while retaining intensive energy use habits. Good use behaviours can significantly reduce energy and water consumption [13].

Despite the controversy, the benefits of green building cannot be overemphasized. It can be measured environmentally, which involves enhancing and protecting biodiversity and ecosystems, improving air and water quality, reducing waste streams and conserving and restoring nat- ural resources [26]. Also, the benefits can be measured economic which involves, reduction in operating costs, higher effective rental income leading to higher financial return, creating and expanding markets for green products and services, improving occupant productivity and optimizing life-cycle economic performance [23]. In addition, the benefits of green building can also be measured socially. These benefits can be seen as enhancing occupant comfort and health, aesthetic qualities, minimizing strain on local infrastructure, and improving the overall quality of life $[26,23]$. Despite the numerous benefits associated with green buildings, the issue of upfront cost is an obstacle that is frequently cited which precludes the widespread adoption of green buildings, which has given birth to this study.

\section{Most Common Features of Green Building}

Five credit categories appear to be ordinary looking at different green building schemes worldwide, which this paper adopted as the basic features of a green building as also used by $[22,26]$ in their respective works. Therefore, to tag a building as the environmentally friendly building must pass the following test:

Water Efficiency: This feature of a green building ensures that the water consumed in and by the facility is adequately utilized since water is a natural resource, hence the need to conserve it. The aim is to increase the efficient use of water within the building by reducing the water needed for operations [25, 36].

Energy Efficiency: Buildings use energy to heat water, lighting, mechanical ventilation and machinery such as lifts. Hence there is a need to control the use of energy. In doing so, the energy systems should be properly installed and calibrated to perform to their intended efficiency levels. This should reduce the overall energy use and lower operating costs. A minimum grade of acceptable energy performance for the facility should be determined and monitored. Green buildings are expected to use sophisticated building automation systems such as indirect computer-controlled lighting to reduce the need for artificial lighting. It should be designed to turn off to reduce energy consumption [25] automatically.

Sustainable Sites: Green buildings are designed to reduce site disturbances. It should preserve existing trees and habitats [25]. In selecting a site for construction, one must ensure that the loca- 
tion poses a minor environmental threat when the building takes place. While considering the site to be chosen, essential factors such as; pollution prevention, soil erosion control, airborne dust generation and waterway sedimentation must be critically evaluated [17].

Materials and Resources: The amount of landfill waste created during construction and operation can be reduced by efficient use of materials and design for recycling, such as the use of recycled concrete aggregate, recycled content materials such as structural steel, ceiling and floor tiles, recycled glass chips for terrazzo floor, carpet fibre sheathing, gypsum wallboard and other materials which should be locally sourced $[17,25,36]$.

Indoor Environmental Quality: For a building to pass the indoor environmental quality test, such a building is expected to adopt sustainable materials and furniture with off-gassing volatile organic compounds [VOCs] [25]. Such facilities should use low emitting materials in construction; ventilation systems that promote outdoor air ventilation; should provide a high amount of fresh air intake [17]; is expected to be smokefree.

\section{Contingent Valuation Method}

The contingent valuation method (CVM) is broadly used for cost-benefit analysis and environmental impact assessments of non-market goods and resources. The way estimates the economic value for the various ecosystem and ecological goods and services. It has been said to calculate both use and non-use values and has proven to be most helpful in assessing the value of non-market goods and services (non-use value) [24]. The method directly asks people in a survey how much they are willing to pay for a particular environmental good or service. It is called contingent valuation because people state their willingness to deliver depending on a hypothetical scenario and description of the ecological interest [6].

The method has been adopted and used to assess the value for green buildings [22, 26], renewable energy [5], forests [9], wetlands [28], watersheds [37], and other non-market resource [33]. Although the contingent valuation method has been criticized for its reliability and validity of results, this problem has been avoided through many scholars' efforts by suggesting best practices for its survey [24, 35].

\section{METHODOLOGY}

This paper employed the quantitative research approach under which the descriptive research design is adopted based on the nature of the investigation. Based on the number of contact with the study population, this study is designed as a cross-sectional study since the study is aimed at finding out how medium-income earners will act in a green residential market. As such, the study investigates the willingness to pay for green building features at one shot by taking a crosssection of the population. In addition, this study is designed as a prospective study based on a reference period since the aim is to forecast the price to be paid for a good yet to be provided or a good that is likely to be provided in the future.

The paper further employed the survey research strategy in which a questionnaire was developed as the instrument for data collection. The questionnaire consisted of three sections, section one bordered on demographic information of the respondents. In contrast, section two consisted of a contingent valuation survey describing the green building. A hypothetical market was created (a three-bedroom green bungalow to be constructed by private investors and sold close to Makurdi International Market). The price medium-income earners will pay was sought using both the payment card method of contingent valuation and the open-ended process of contingent valuation. The third section of the questionnaire centred on information regarding green building features.

Data for the study was obtained from the population of the study, which are medium income householders of; BIPC Housing Estate Nyiman, BIPC Ever Green Housing Estate North Bank, Aper Aku Housing Estate, Eskay Housing Estate Naka Road, Eskay Housing Estate Akpehe and Grace land Housing Estate. It is noteworthy that the scope of this work narrows the population for the study to only include householders of the above housing estate since there were constructed for the middle-income class, and their housing size and neighbourhood characteristic (medium dense neighbourhood) best suits mediumincome households [19].

The sample frame for the study amounted to 552 medium-income householders. A sample size of 300 was drawn out using Krejcie and Morgan table and adjusted to take care of the uncertainty of all householders responding to the survey missing data and outliers' exclusion. The study adopted the stratified sampling technique. Six 
strata were created such that the householders of each of the housing estates formed a stratum. As it is familiar with surveys, about 26 questionnaires $(8.7 \%)$ were not returned by the respondents, therefore amounting to a total retrieved number of 274 questionnaires.

The data collected were analyzed using descriptive and inferential statistics with the Statistical Package for the Social Sciences (SPSS). For the first objective, the Relative Preference Index was employed to analyze data where the weighted mean of responses from a six-point Likert scale was computed. Then, a decision was made using the scale presented in Table 1.

Table 1 - Decision Making Bench Mark (Likert Scale) [26]

\begin{tabular}{|l|l|l|}
\hline Points & Decision & Bench Mark \\
\hline 1 & Extremely Not Important & $1.00-1.49$ \\
\hline 2 & Highly Not Important & $1.50-2.49$ \\
\hline 3 & Not Important & $2.50-3.49$ \\
\hline 4 & Important & $3.50-4.49$ \\
\hline 5 & Highly Important & $4.50-5.49$ \\
\hline 6 & Extremely Important & $5.50-6.00$ \\
\hline
\end{tabular}

The second objective, which involved estimating the value householders' are willing to pay for a 3bedroom green building, was analyzed using an econometric model (binary logistic). The logistic model explains the willingness to pay (WTP) as a function of observable characteristics of the respondents [2]. The mean willingness to pay (MWTP) was then computed from the output of the binary logistic model using the equation below:

$$
\text { MWTP }=\frac{-\alpha}{\beta 1}
$$

where: $\alpha=$ Intercept; $\beta 1=$ Coefficient of Bid Value

The third objective was analyzed using a multiple regression model. The effect of satisfaction with conventional housing attributes and preference for green building features on the amount householders are willing to pay was tested.

\section{RESULTS AND DISCUSSION}

\section{Makurdi Medium Income Householders' Preference of Green Residential Building Features}

Table 2 reveals that among all the five most common green building features, Makurdi medium-income householders opined that Indoor Environmental Quality, Sustainable Site, Energy Efficiency and Building Materials/Resource were significant to them, recording mean values of 5.16, 5.00, 4.81 and 4.56, respectively. On the other hand, regarding Water Efficiency, house householders revealed that it was simply necessary to have a recorded mean value of 4.49 . Therefore, it can be said that Makurdi mediumincome householders prefer each of the five green features in the following order; Indoor Environmental Quality, Sustainable Site, Energy Efficiency, Building Materials/Resource, and Water Efficiency.

Table 2 - Preference of Green Residential Building Features

\begin{tabular}{|l|c|c|c|c|c|c|}
\hline & $\mathrm{N}$ & Minimum & Maximum & Mean & Std. Deviation & Rank \\
\hline P1 & 272 & 1 & 6 & 4.64 & 1.084 & I \\
\hline P2 & 274 & 1 & 6 & 4.30 & 1.191 & VI \\
\hline P3 & 272 & 1 & 6 & 4.44 & 1.180 & IV \\
\hline P4 & 273 & 1 & 6 & 4.63 & 1.128 & II \\
\hline P5 & 272 & 1 & 6 & 4.39 & 1.206 & V \\
\hline P6 & 270 & 1 & 6 & 4.54 & 1.054 & III \\
\hline Water Efficiency & 274 & 1.83 & 6.00 & 4.4853 & .82741 & 5 \\
\hline P7 & 274 & 1 & 6 & 4.75 & 1.062 & IV \\
\hline P8 & 273 & 1 & 6 & 5.00 & .968 & I \\
\hline P9 & 272 & 1 & 6 & 4.66 & 1.125 & VI \\
\hline P10 & 272 & 1 & 6 & 4.64 & 1.006 & VII \\
\hline P11 & 272 & 2 & 6 & 4.94 & .911 & II \\
\hline P12 & 274 & 1 & 6 & 4.75 & .975 & IV \\
\hline P13 & 274 & 1 & 6 & 4.90 & .932 & III \\
\hline Energy Efficiency & 274 & 2.00 & 6.00 & 4.8056 & .78484 & 3 \\
\hline
\end{tabular}




\begin{tabular}{|l|c|c|c|c|c|c|}
\hline & $\mathrm{N}$ & Minimum & Maximum & Mean & Std. Deviation & Rank \\
\hline P14 & 274 & 2 & 6 & 4.95 & .934 & IV \\
\hline P15 & 273 & 1 & 6 & 4.80 & 1.107 & V \\
\hline P16 & 274 & 2 & 6 & 5.03 & .891 & II \\
\hline P17 & 274 & 1 & 6 & 5.02 & .904 & III \\
\hline P18 & 274 & 1 & 6 & 5.18 & .905 & I \\
\hline Sustainable Site & 274 & 2.00 & 6.00 & 4.9956 & .75727 & 2 \\
\hline P19 & 271 & 1 & 6 & 4.37 & 1.309 & II \\
\hline P20 & 274 & 1 & 6 & 4.75 & 1.115 & I \\
\hline Building materials & 274 & 1.00 & 6.00 & 4.5584 & 1.06916 & 4 \\
\hline P21 & 274 & 2 & 6 & 5.20 & .831 & I \\
\hline P22 & 274 & 2 & 6 & 5.11 & .898 & II \\
\hline Indoor environmental quality & 274 & 2.00 & 6.00 & 5.1551 & .80442 & 1 \\
\hline Preference & 274 & 2.27 & 6.00 & 4.7717 & .70431 & \\
\hline
\end{tabular}

To measure preference of Indoor Environmental Quality, two items were used [High Ventilating Windows (P21) and Large Size of Room (P22)], which householders opined that both things were essential to them with a recorded mean of 5.20 and 5.11 respectively. Preference of sustainable site adopted five items of measurement. The items are Infrastructure Availability (P14), Proximity to Urban Development (P15), Availability of Trees and Habitant (P16), Pollution Prevention (P17) and Erosion Control (P18). Similarly, householders perceived all the five items to be very important to them with mean values of 4.95 , $4.80,5.03,5.02$ and 5.18, respectively.

Preference of Energy Efficiency was measured using seven items, in which householders revealed that all seven things were essential to them and preferred each of them in this order; Energy Efficient Bulbs (P8) with a mean of 5.00, Solar/Wind Energy (P11) with mean of 4.94, Energy Certified Appliances (P13) with a standard of 4.90, Computer Controlled Lighting(P7) with a mean value of 4.75, Refrigerator Management System (P12) with mean of 4.75, Significant Daylighting Building Design (P9) with mean of 4.66 and LED Lighting Design (P10) with a mean of 4.64. Preference for Sustainable Building the Material feature of green building was measured using two items, Locally Sourced Building Materials (P14) with a standard of 4.37, which suggests that this item is essential to Makurdi medium-income householders. The second item that measured preference for Sustainable Building Materials was renewable construction materials (P20) which recorded a mean value of 4.75, which is interpreted to be very important to them.
Water Efficiency preference was measured using six items of measurement. Medium-income householders opined that three of the items were very important to them and their order of choice for these items were as follows; Innovative Waste Management Technology (P1) having a recorded mean of 4.64, Innovative Rain Water Harvesting Technology (P4) having a recorded mean of 4.63 and Use of Bio-Swales/Bio-Filters (P6) having a documented standard of 4.54 . Nevertheless, householders perceived three of the items used to measure preference of water efficiency to be important to them in this order simply; Low Flow WC (P3) with a mean of 4.44, Gray Water Recycling Technology (P5) with a standard of 4.39 and Waterless Urinals (P2) with a mean of 4.30 .

This finding is closely related to [29], as most of the same green features were mostly preferred by residents of Canberra, Australia. Equally, estate surveyors and valuers in Lagos expressed a preference for most green features to conventional elements in the study conducted by [15], which is similar to the opinion of Makurdi medium-income residents.

\section{Estimated Amount Medium Income Earners will pay for Three Bedroom Green Residential Bungalow}

The result of the binary logistic regression is presented in Table 3 which the intercept and the bid coefficient is extracted to compute the mean willingness to pay.

Table 3 shows the coefficient of $\beta 1$ to be 0.00004549 and $\alpha$ as -700.877 . The result showed that Makurdi medium-income householders are willing to purchase a three-bedroom green bungalow at an estimated price of $\$ 15,407,276.32$ (Say; $\$ 15,500,000$ ). 
Table 3 - Parameter Estimates from Logistic Model

\begin{tabular}{|c|c|c|c|c|c|c|c|}
\hline \multirow[b]{2}{*}{ Parameter } & \multirow[b]{2}{*}{$\beta$} & \multirow[b]{2}{*}{ Std. Error } & \multicolumn{2}{|c|}{ 95\% Wald Confidence Interval } & \multicolumn{3}{|c|}{ Hypothesis Test } \\
\hline & & & Lower & Upper & Wald Chi-Square & $\mathrm{df}$ & Sig. \\
\hline (Intercept) & -700.877 & 41582.3907 & -82200.865 & 80799.111 & .000 & 1 & .987 \\
\hline Age & .597 & 1399.6151 & -2742.598 & 2743.792 & .000 & 1 & 1.000 \\
\hline Persons & .416 & 1124.5707 & -2203.702 & 2204.535 & .000 & 1 & 1.000 \\
\hline Education & -.053 & 1678.8171 & -3290.474 & 3290.368 & .000 & 1 & 1.000 \\
\hline Income & -.724 & 1303.5567 & -2555.648 & 2554.200 & .000 & 1 & 1.000 \\
\hline Bid & $4.549 \mathrm{E}-5$ & .0026 & -.005 & .005 & .000 & 1 & .986 \\
\hline (Scale) & $1 \mathrm{a}$ & & & & & & \\
\hline
\end{tabular}

By extension, it can be said that Makurdi medium-income householders are willing to pay a $3.3 \%$ premium for green features considering the price to purchase a new high standard threebedroom conventional building in Makurdi. This finding is closely related to the results of [20], who in their study revealed that commercial and industrial building users of Ibadan, Nigeria were willing to pay a premium of between $1 \%$ and $10 \%$.

\section{Effect of Preference for Green Building features on the Amount Willing to Pay}

This study measured if the preference for green building features affects Makurdi mediumincome householders' willingness to pay for a green building and the pattern of such effect. The regression model was built to include the preference of each of the five green features as the predictors to explain how each of the green features contributes to the amount willing to pay.

Table 4 - Multiple Regression Model Summary

\begin{tabular}{|l|c|c|c|c|c|c|c|c|c|}
\hline \multirow{2}{*}{ Model } & \multirow{2}{*}{$\mathrm{R}$} & \multirow{2}{*}{$\mathrm{R}^{2}$} & Adjusted $\mathrm{R}^{2}$ & \multirow{2}{*}{$\begin{array}{c}\text { Std. Error of the } \\
\text { Estimate }\end{array}$} & \multicolumn{5}{|c|}{ Change Statistics } \\
\cline { 5 - 9 } & & & $\mathrm{R}^{2}$ Change & $\begin{array}{c}\mathrm{F} \\
\text { Change }\end{array}$ & $\mathrm{df1}$ & $\mathrm{df2}$ & $\begin{array}{c}\text { Sig. F } \\
\text { Change }\end{array}$ \\
\hline 1 & $.312 \mathrm{a}$ & .097 & .079 & 3374602.562 & .097 & 5.208 & 5 & 242 & .000 \\
\hline
\end{tabular}

Table 4 reveals a $31.2 \%$ relationship between the predictors (preference for the five green features) and the dependent variable (amount willing to pay). This is seen with an R-value of 0.312 . In addition, the $\mathrm{R}^{2}$ of 0.097 suggests that preference for green building features has a $9.7 \%$ collective influence on the amount willing to pay. That is to say, the predictor variables account for a $9.7 \%$ variance in the dependent variable, whereas $90.3 \%$ of the conflict in the amount willing to pay is accounted for by other factors not considered in the model. The p-value further tells that the effect of the predictor variables on the dependent variable is significant since the $p$ value is less than 0.01 .
The Unstandardized $\beta$ Coefficients in Table 5 further reveal that; a unit increase of water efficiency (PWE) will lead to an $\$ 422,735.51$ decrease in the amount willing to pay, while a unit increase of energy efficiency (PEE) will result to \#614,262.46 increase in the amount willing to pay. Also, a unit increase of sustainable site (PSS) will result in an $\$ 540,105.47$ rise in the amount willing to pay. In contrast, a unit increase in sustainable building materials (PSBM) will lead to an \#396,934.23 increase in the willingness to pay. In addition, a unit increase in indoor environmental quality (PIEQ) will increase the amount willing to pay by $\$ 1,223,980.87$. 


\begin{tabular}{|c|c|c|c|c|c|c|c|c|}
\hline \multirow{2}{*}{\multicolumn{2}{|c|}{ Model }} & \multicolumn{2}{|c|}{ Unstandardized Coefficients } & \multirow{2}{*}{$\begin{array}{c}\begin{array}{c}\text { Standardized } \\
\text { Coefficients }\end{array} \\
\text { Beta }\end{array}$} & \multirow[b]{2}{*}{$\mathrm{t}$} & \multirow[b]{2}{*}{ Sig. } & \multicolumn{2}{|c|}{$\begin{array}{c}\text { Collinearity } \\
\text { Statistics }\end{array}$} \\
\hline & & $\mathrm{B}$ & Std. Error & & & & Tolerance & VIF \\
\hline \multirow[t]{6}{*}{1} & (Constant) & 9673368.280 & 1592302.886 & & 6.075 & .000 & & \\
\hline & PWE & -422735.514 & 389776.996 & -.094 & $\begin{array}{c}- \\
1.085\end{array}$ & .279 & .501 & 1.996 \\
\hline & PEE & 614262.460 & 493665.817 & .131 & 1.244 & .215 & .336 & 2.978 \\
\hline & PSS & 540105.474 & 580517.093 & -.112 & -.930 & .353 & .258 & 3.870 \\
\hline & PSBM & 396934.232 & 302019.561 & .109 & 1.314 & .190 & .537 & 1.860 \\
\hline & PIEQ & 1223980.866 & 505284.493 & .271 & 2.422 & .016 & .299 & 3.344 \\
\hline
\end{tabular}

a. Dependent Variable: Amount Willing to Pay

\section{CONCLUSIONS}

This study has concluded that Makurdi mediumincome earners are willing to pay a 3.3\% premium price for green residential building features, which suggests a low premium regarding the viability of such an investment considering the economic implication of acquiring the green technology in Nigeria and the financial standing of the nation. However, suppose awareness is created on green building and its benefits. In that case, Makurdi medium-income earners will be likely to pay more to purchase green homes, which may increase the premium to pay for green building features to a more realizable value. Therefore, government and private investors may consider delving into such a project considering the militating factors.
The study recommends that the government and private investors venture into providing green residential buildings in faces. The quantities of units increase gradually to allow the product to create awareness for itself gradually, which will likely lead to more demand transcending to a higher price. Also, more attention should be made to the importance of building green. At the same time, the government equally need to come up with a green housing policy that will promulgate a green building certification scheme of $\mathrm{Ni}$ geria that will define and regulate the development of the building industry, turning design, construction and operation of building towards sustainability while also making mortgage readily available and at attractive rates to those willing to build green.

\section{REFERENCES}

1. Abdullahi, O. L. (2021). Social Welfare and Access to Housing Among the Middle and Low-income Earners in Nigeria: A Review of Frameworks for Housing Delivery. Public Policy and Administration Research, 11(1), 90-97. doi: 10.7176/ppar/11-1-08

2. Adamu, A., Yacob, M. R., Radam, A., \& Hashim, R. (2015). Factors Determining Visitors' Willingness to Pay for Conservation in Yankari Game Reserve, Bauchi, Nigeria. International Journal of Economics and Management, 9(5), 95-114.

3. Akadiri, P. O., Chinyio, E. A., \& Olomolaiye, P. O. (2012). Design of A Sustainable Building: A Conceptual Framework for Implementing Sustainability in the Building Sector. Buildings, 2(2), 126-152. doi: 10.3390/buildings2020126

4. Altomonte, S., Schiavon, S., Kent, M. G., \& Brager, G. (2017). Indoor environmental quality and occupant satisfaction in green-certified buildings. Building Research \& Information, 47(3), 255274. doi: 10.1080/09613218.2018.1383715

5. Botelho, A., Pinto, L. M. C., Lourenço-Gomes, L., Valente, M., \& Sousa, S. (2016). Social sustainability of renewable energy sources in electricity production: An application of the contingent valuation method. Sustainable Cities and Society, 26, 429-437. doi: 10.1016/j.scs.2016.05.011 
6. Caxton, G. K. (2016). The Concept of Total Economic Value in Environmental Management. Retrieved from

https://www.academia.edu/19108836/The_concept_of_total_economic_value_in_environmenta l_management

7. Centre for Affordable Housing Finance in Africa. (2019). Understanding Nigeria's Housing Finance Market. Retrieved from http://housingfinanceafrica.org/app/uploads/Nigeria-July-2019.pdf

8. Galli, A., Iha, K., Moreno Pires, S., Mancini, M. S., Alves, A., Zokai, G., ... Wackernagel, M. (2020). Assessing the Ecological Footprint and biocapacity of Portuguese cities: Critical results for environmental awareness and local management. Cities, 96, 102442. doi:

10.1016/j.cities.2019.102442

9. Henry, M., Mittelhammer, R. C., \& Loomis, J. B. (2018). An information theoretic approach to estimating willingness to pay for river recreation site attributes. Water Resources and Economics, 21,17-28. doi: 10.1016/j.wre.2017.10.006

10. Hill, A., Han, Y., Taylor, J. E., Shealy, T., Pearce, A., \& Mohammadi, N. (2019). Empirical Examination of Pro-environmental Behaviors in Traditional, Green Featured, and LEED Certified Buildings. Energy Procedia, 158, 3982-3987. doi: 10.1016/j.egypro.2019.01.843

11. Illankoon, I. M. C. S., Tam, V. W. Y., Le, K. N., \& Shen, L. (2017). Key credit criteria among international green building rating tools. Journal of Cleaner Production, 164, 209-220. doi: 10.1016/j.jclepro.2017.06.206

12. Jerry, Y. (2005, February). Where Are All the LEED Projects? Retrieved from https://www.sundt.com/2015/02/09/top-ten-states-for-leed/

13. Kamilaris, A., Neovino, J., Kondepudi, S., \& Kalluri, B. (2015). A case study on the individual energy use of personal computers in an office setting and assessment of various feedback types toward energy savings. Energy and Buildings, 104, 73-86. doi: 10.1016/j.enbuild.2015.07.010

14. Klarin, T. (2018). The Concept of Sustainable Development: From its Beginning to the Contemporary Issues. Zagreb International Review of Economics and Business, 21(1), 67-94. doi: 10.2478/zireb-2018-0005

15. Komolafe, M. O., Oyewole, M. O. (2015). Perception of estate surveyors and valuers on users' preference for green building in Lagos, Nigeria. Retrieved from https://www.researchgate.net/publication/281291606_PERCEPTION_OF_ESTATE_SURVEYOR S_AND_VALUERS_ON_USERS'_PREFERENCE_FOR_GREEN_BUILDING_IN_LAGOS_NIGERIA

16. Kuma, S. S., \& Fabunmi, F. O. (2016). Emerging issues in housing affordability in Makurdi, Nigeria. Inclusive City Growth and the Poor: Policies, Challenges and Prospects. Retrieved from https://www.researchgate.net/publication/326468583_Emerging_issues_in_housing_affordabil ity_in_Makurdi_Nigeria

17. De Luca, P., Carbone, I., \& Nagy, J. B. (2017). Green building materials: a review of state of the art studies of innovative materials. Journal of Green Building, 12(4), 141-161. doi: 10.3992/19434618.12.4.141

18. Oguntona, O. A., \& Aigbavboa, C. O. (2017). Biomimicry principles as evaluation criteria of sustainability in the construction industry. Energy Procedia, 142, 2491-2497. doi: 10.1016/j.egypro.2017.12.188

19. Okpoechi, C. U. (2014). Middle-Income Housing in Nigeria: Determining Important Functional Requirements for Mass Housing Design. Journal of Architecture Research, 4(1A), 9-14.

20. Olaleye, A., Ayodele, T. O., \& Komolafe, M. O. (2015). The Relevance of Green Building Practice in Emerging Markets: A Perceptual Analysis of Commercial and Industrial Building Users in Ibadan, Nigeria. Journal of Sustainable Real Estate, 7(1), 41-59. 
21. Olanipekun, A. O., Xia, B., Hon, C., \& Darko, A. (2018). Effect of Motivation and Owner Commitment on the Delivery Performance of Green Building Projects. Journal of Management in Engineering 34(1), 1-14.

22. Otegbulu, A. C. (2018). Willingness to Pay for Sustainable Features in Prime Residential Submarkets of Lagos. Journal of Sustainable Real Estate, 10(1), 163-189. doi: 10.1080/10835547.2018.12091908

23. Oyedokun, T. B. (2017). Green premium as a driver of green-labelled commercial buildings in the developing countries: Lessons from the UK and US. International Journal of Sustainable Built Environment, 6(2), 723-733. doi: 10.1016/j.ijsbe.2017.12.007

24. Quah, E., \& Tan, T. S. (2019, October). Valuing the Environment. Retrieved from https://www.adb.org/sites/default/files/publication/532731/adbi-wp1012.pdf

25. Rashid, M., Spreckelmeyer, K., \& Angrisano, N. J. (2012). Green buildings, environmental awareness, and organizational image. Journal of Corporate Real Estate, 14(1), 21-49. doi: $10.1108 / 14630011211231428$

26. Robinson, S., Simons, R., Lee, E. \& Kern, A. (2016). Demand for Green Buildings: Office Tenants' Stated Willingness-to-Pay for Green Features. Journal of Real Estate Research, 38(3), 423-452. doi: 10.1080/10835547.2016.12091450

27. Asún, R. A., Rdz-Navarro, K., \& Alvarado, J. M. (2015). Developing Multidimensional Likert Scales Using Item Factor Analysis. Sociological Methods \& Research, 45(1), 109-133. doi: 10.1177/0049124114566716

28. Siew, M. K., Yacob, M. R., Radam, A., Adamu, A., \& Alias, E. F. (2015). Estimating Willingness to Pay for Wetland Conservation: A Contingent Valuation Study of Paya Indah Wetland, Selangor Malaysia. Procedia Environmental Sciences, 30, 268-272. doi: 10.1016/j.proenv.2015.10.048

29. Tapsuwan, S., Mathot, C., Walker, I., \& Barnett, G. (2018). Preferences for sustainable, liveable and resilient neighbourhoods and homes: A case of Canberra, Australia. Sustainable Cities and Society, 37, 133-145. doi: 10.1016/j.scs.2017.10.034

30. Udomiaye, E., \& Chukwuali, B. (2019). Advances in building environmental sustainability assessment tools/methods and the Nigeria context: a review. International Journal of Civil Engineering, Construction and Estate Management, 7(2), 30-41.

31. United Nations Development Programme. (2015). Sustainable Development Goals. Retrieved from https://sdgs.un.org/ru/goals

32. USGBC. (2009). Cost of Green in NYC. Retrieved from https://www.urbangreencouncil.org/content/projects/cost-green-nyc

33. Wang, J., Ge, J., \& Gao, Z. (2018). Consumers' Preferences and Derived Willingness-to-Pay for Water Supply Safety Improvement: The Analysis of Pricing and Incentive Strategies. Sustainability, 10(6), 1704. doi: 10.3390/su10061704

34. Xie, X., Lu, Y., \& Gou, Z. (2017). Green Building Pro-Environment Behaviors: Are Green Users Also Green Buyers? Sustainability, 9(10), 1703. doi: 10.3390/su9101703

35. Xiong, K., Kong, F., Zhang, N., Lei, N., \& Sun, C. (2018). Analysis of the Factors Influencing Willingness to Pay and Payout Level for Ecological Environment Improvement of the Ganjiang River Basin. Sustainability, 10(7), 2149. doi: 10.3390/su10072149

36. Yau, Y. (2012). Willingness to pay and preferences for green housing attributes in Hong Kong. Journal of Green Building, 7(2), 137-152. doi: 10.3992/jgb.7.2.137

37. Zhou, C. \& Li, G. P. (2015). The Influencing Factors for Willingness to Pay of Payment for Watershed Services:A Case of the Water Receiving Area of Zhengzhou City of the Middle Route Project of the South-North Water Transfer Project. Retrieved from http://en.cnki.com.cn/Article_en/CJFDTotal-JJDL201506006.htm 